Life after Guns 


\section{The Rutgers Series in Childhood Studies}

The Rutgers Series in Childhood Studies is dedicated to increasing our understanding of children and childhoods throughout the world, reflecting a perspective that highlights cultural dimensions of the human experience. The books in this series are intended for students, scholars, practitioners, and those who formulate policies that affect children's everyday lives and futures.

Edited by Jill E. Korbin, Associate Dean, College of Arts and Sciences; Professor, Department of Anthropology; Director, Schubert Center for Child Studies; Co-Director, Childhood Studies Program, Case Western Reserve University

Elisa (EJ) Sobo, Professor of Anthropology, San Diego State University

\section{Editorial Board}

Mara Buchbinder, Assistant Professor, Department of Social Medicine, University of North Carolina, Chapel Hill Meghan Halley, Assistant Scientist, Palo Alto Medical Foundation

David Lancy, Emeritus Professor of Anthropology, Utah State University Heather Montgomery, Reader, Anthropology of Childhood, Open University (UK)

David Rosen, Professor of Anthropology and Sociology, Fairleigh Dickinson University

Rachael Stryker, Assistant Professor of Department of Human

Development and Women's Studies, California State University, East Bay

Tom Weisner, Professor of Anthropology, University of California,

Los Angeles

Founding Editor: Myra Bluebond-Langner, UCL-Institute of Child Health

For a list of all the titles in the series, please see the last page of the book. 


\title{
Life after Guns
}

\author{
Reciprocity and Respect \\ among Young Men in Liberia
}

\author{
ABBY HARDGROVE
}

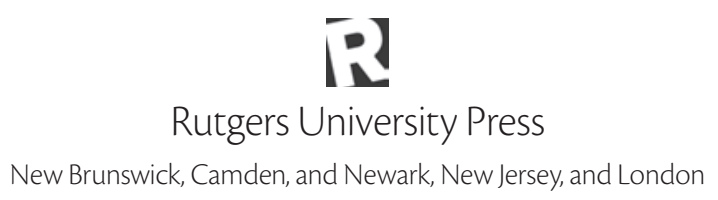




$$
\begin{aligned}
& 97^{8-0-8} \mathrm{I} 35^{-7} 7348-9 \\
& 97^{-0}-0-8 \mathrm{I} 35^{-} 7347^{-2} \\
& 978-0-8 \mathrm{I} 35^{-} 7350-2 \\
& 978-0-8 \mathrm{I} 35^{-7} 7349^{-6}
\end{aligned}
$$

Cataloging-in-Publication data is available from the Library of Congress.

A British Cataloging-in-Publication record for this book is available from the British Library.

\section{Copyright $\left({ }^{2} 2017\right.$ by Abby Hardgrove}

All rights reserved

No part of this book may be reproduced or utilized in any form or by any means, electronic or mechanical, or by any information storage and retrieval system, without written permission from the publisher. Please contact Rutgers University Press, Io6 Somerset Street, New Brunswick, NJ 0890I. The only exception to this prohibition is "fair use" as defined by U.S. copyright law.

$\infty$ The paper used in this publication meets the requirements of the American National Standard for Information Sciences-Permanence of Paper for Printed Library Materials, ANSI Z $39 \cdot 48-$ I992.

www.rutgersuniversitypress.org

Manufactured in the United States of America 
For those whose lives fill these pages and for those who read them. We are all students of our human condition and of the worlds in which we live. 
